\title{
Removal of fluoride from aqueous solution by adsorption on lanthanum modified attapulgite
}

\author{
Wang Jiahong * \\ College of Resource and Environment, \\ Shaanxi University of Science \& Technology, \\ Xi'an 710021, P.R China. \\ E-mail: wangjiahong@sust.edu.cn
}

\author{
Y in Xiaolong \\ College of Resource and Environment, \\ Shaanxi University of Science \& Technology, \\ Xi'an 710021, P.R China. \\ E-mail: 527643616@qq.com
}

\begin{abstract}
Fluoride pollution in natural water may create severe threats for human health. In this study, lanthanum modified attapulgite (La-ATP) was synthesized and used as a novel adsorbent for removal of fluoride in aqueous solution. Characterized results showed that the mass content of Lanthanum oxide was $3.30 \%$. La-ATP exhibited high adsorption affinity for aqueous fluoride and the maximum adsorption amounts were $16.92,22.03$ and $25.91 \mathrm{mg} / \mathrm{g}$ at 15 , 25 and $35{ }^{\circ} \mathrm{C}$, respectively. Adsorption kinetic followed pseudo-second kinetics model and adsorption rates decreased with increasing initial concentration of fluoride. The amount adsorbed of fluoride onto La-ATP decreased generally with increasing solution $\mathrm{pH}$. The presence of coexisted anions in water decreased the adsorption amount of fluoride by competitive adsorption. Fluoride loaded LaATP can be easily desorbed in alkaline solution and the regenerated adsorbent still possessed high adsorption capacity for aqueous fluoride. The results implied that LaATP may be an efficient adsorbent for the removal of aqueous fluoride.
\end{abstract}

Keywords- Lanthanum modified attapulgite; adsorption; desorption; fluoride

\section{INTRODUCTION}

Fluoride pollution in the environment can occur due to natural sources and anthropogenic sources [1]. Fluoride frequently exists in minerals and it can be leached out due to erosion by rainwater, thereby allowing it to contaminate ground and surface water. On the other hand, fluorine compounds are industrially important and are extensively used in glass and semiconductors manufacturing, fertilizers operation, steel and aluminum industries, and nuclear applications [2]. Fluoride is one of the essential trace elements for human body [3]. Excess fluoride in drinking water causes harmful effects such as dental and skeletal fluorosis [4]. The presence of fluorine in drinking water is beneficial to the production and maintenance of healthy bones and teeth when its content is within permissible limits[3]. Long term ingestion of high fluoride drinking water may cause dental or skeletal fluorosis [5]. The World Health Organization has set a guidance value of $1.5 \mathrm{mg} / \mathrm{L}$ for fluoride in drinking water $[6,7]$. China also adopted $1.0 \mathrm{mg} / \mathrm{L}$ as the upper limit.

Various methods such as chemical precipitation [8], ion exchange [9], electrodialysis and electrolysis [10, 11], and adsorption [12] were developed to remove fluorides in aqueous solution. Among these methods, adsorption is still an effective and one of the most suitable methods for defluoride of water because it is economical, environmentally benign and efficient $[13,14]$. In recent years, many adsorbents have been reported to be effective for removal of aqueous fluoride, such as activated carbon [14], alumina and its composites [15, 16], fly ash [13, 17], clay minerals $[18,19]$, chitosan [20], resins [21], and so on. Among these, clay mineral adsorbents have received great attention because they are natural, inexpensive.

Attapulgite (ATP) is a kind of crystalline hydrated magnesium aluminum silicate mineral, which has been extensively used as adsorbents to remove the organic and inorganic pollutants because of its porous structure, high surface area and low cost [22]. However, removal of fluoride from aqueous solution by adsorption onto attapulgite is very limited. Numerous studies have shown that lanthanum-based adsorbents, such as La-incorporated chitosan beads [23], La-resin [24], La loaded natural zeolite [25], lanthanum-impregnated silica gel [26], have a high affinity for fluoride in aqueous solution. Therefore, lanthanum modified attapulgite (La-ATP) may improve the adsorption capacity for fluoride. To our best knowledge, no efforts have been made to develop lanthanum modified attapulgite to remove the aqueous fluoride.

In this study, lanthanum modified attapulgite were prepared and used as a novel adsorbent for the removal of fluoride. Adsorption and desorption behaviors of aqueous fluoride on La-ATP were studied by batch experiments. Effect of solution chemistry properties such as solution $\mathrm{pH}$ and competitive anions on fluoride adsorption was also described.

\section{EXPERIMENTAL}

\section{A. Materials}

Attapulgite (100 mesh) was purchased from HuiDa Mining Technology Co., Ltd., Jiangsu, China. Lanthanum(III) nitrate $\left(\mathrm{La}\left(\mathrm{NO}_{3}\right)_{3} \cdot 6 \mathrm{H}_{2} \mathrm{O}\right)$ and other reagents of analytical grade were obtained from Sinopharm Chemical Reagent Co., Ltd., Shanghai, China.

\section{B. Preparation of adsorbent}

Typically, $10 \mathrm{~g}$ attapulgite powder was dispersed in $150 \mathrm{ml}$ deionised water, and was sonicated at a power setting of $300 \mathrm{~W}$ for $20 \mathrm{~min}$. After settling for a few minutes, the bottom sediment is drained, followed by filtering and drying. Five grams treated attapulgite were dispersed in $100 \mathrm{ml}$ hydrochloric acid of $1 \mathrm{~mol} / \mathrm{L}$, and the 
mixture was stirred magnetically for $2 \mathrm{~h}$ at room temperature. The solid was filtrated and washed deionized water until $\mathrm{pH} 6$, and dried at $100{ }^{\circ} \mathrm{C}$ at vacuum drying chamber. The resulting solid was referred as $\mathrm{HCl}$ attapulgite.

Five milligram of $\mathrm{HCl}$-attapulgite and $0.94 \mathrm{~g}$ $\mathrm{La}\left(\mathrm{NO}_{3}\right)_{3} \cdot 6 \mathrm{H}_{2} \mathrm{O}$ was dispensed in $200 \mathrm{~mL}$ deionised water. Complete dispersion of the clay was achieved by stirring the slurry at the room temperature for $2 \mathrm{~h}$. The mixture was kept in $80 \mathrm{oC}$ under constant stirring for $48 \mathrm{~h}$, followed by filtering and washing with deionised water, then dried at vacuum drying oven and calcinated at 300 $\mathrm{oC}$ for $2 \mathrm{~h}$. Then lanthanum modified attapulgite (La-ATP) was obtained.

\section{Characterization of La-ATP}

The mineralogical and chemical compositions of natural attapulgite and La-ATP were determined by X-ray fluorescence (XRF, Eval).

\section{Adsorption experiment}

A stock solution containing $1000 \mathrm{mg} / \mathrm{L}$ fluoride was prepared by dissolving appropriate amount of sodium fluoride in double distilled water. Experimental solutions for adsorption and analysis were then prepared freshly by diluting the stock solution. Typically, $20 \mathrm{mg}$ of La-ATP was added to $40 \mathrm{ml}$ of fluoride solution with $\mathrm{pH} 6.0$ and the initial concentration in the range of $5 \sim 60 \mathrm{mg} / \mathrm{L}$. The suspensions were mixed in incubator shaker at 15,25 , and $35{ }^{\circ} \mathrm{C}$ and shaken for $4 \mathrm{~h}$. After reaching adsorption equilibrium, the solution was filtered through $0.45 \mu \mathrm{m}$ membrane and the filtrate was analyzed for residual fluoride concentration by ion selective electrode [27]. The adsorption amount of fluoride on La-ATP was calculated using the following equation:

$$
q_{e}=\frac{\left(C_{0}-C_{e}\right) \cdot V}{W}
$$

Where $C_{0}(\mathrm{mg} / \mathrm{L})$ is the initial concentration of fluoride, $C_{e}(\mathrm{mg} / \mathrm{L})$ is the equilibrium concentration of fluoride, $V(\mathrm{~L})$ is the volume of solution, and $W(\mathrm{~g})$ is the weight of La-ATP.

For adsorption kinetics experiments at $25{ }^{\circ} \mathrm{C}, 200 \mathrm{mg}$ La-ATP was added into $400 \mathrm{ml}$ fluoride solution at $\mathrm{pH}$ value of 6.0 and initial concentration of 10, 30, and 50 $\mathrm{mg} / \mathrm{L}$, respectively under strong magnetic stirring. At selected time periods, a certain amount of sample was withdrawn from the flask and filtrated. The residual fluoride concentration in solution was determined by ion selective electrode.

The $\mathrm{pH}$ effect on fluoride adsorption was investigated in a $\mathrm{pH}$ range from 3 to 11 . a series of glass tubes receiving $20 \mathrm{mg} \mathrm{La}-\mathrm{ATP}$ and $40 \mathrm{ml}$ of $50 \mathrm{mg} / \mathrm{L}$ fluoride solution was pre-adjusted to the desired $\mathrm{pH}$ value by $0.1 \mathrm{~mol} / \mathrm{L} \mathrm{HCl}$ or $0.1 \mathrm{~mol} / \mathrm{L} \mathrm{NaOH}$ and shaken at $25{ }^{\circ} \mathrm{C}$ for $4 \mathrm{~h}$. Effect of competitive ions on fluoride adsorption was studied by dispersing $20 \mathrm{mg}$ La-ATP in $40 \mathrm{ml}$ of $\mathrm{NaCl}, \mathrm{NaNO}_{3}, \mathrm{Na}_{2} \mathrm{SO}_{4}$, or $\mathrm{Na}_{2} \mathrm{CO}_{3}$ solution $(5-25 \mathrm{mmol} / \mathrm{L})$ containing $50 \mathrm{mg} / \mathrm{L}$ fluoride at $\mathrm{pH} 6.0$ and $25^{\circ} \mathrm{C}$.

\section{E. Desorption and regeneration}

To examine the desorption property of fluoride from La-ATP adsorbent, $100 \mathrm{mg}$ La-ATP was placed into 40 $\mathrm{ml}$ of $50 \mathrm{mg} / \mathrm{L}$ fluoride solution. After fluoride adsorption at pH 6.0 and $25^{\circ} \mathrm{C}$ for $4 \mathrm{~h}$, fluoride loaded La-ATP was separated centrifugally and regenerated in $25 \mathrm{ml}$ of 0.1 mol/L $\mathrm{NaOH}$ solution for $2 \mathrm{~h}$. Then regenerated La-ATP was separated centrifugally and washed with deionized water for three times to remove any unadsorbed fluoride. The adsorption and regeneration experiments were followed for 4 cycles.

\section{RESULTS AND DISCUSSION}

\section{A. Adsorbent characterization}

The chemical composition of ATP and La-ATP characterized by X-ray fluorescence analyses were tabulated in Table 1. From the results, the attapulgite was successfully modified by lanthunum and the mass content of $\mathrm{La}_{2} \mathrm{O}_{3}$ was $3.30 \%$. And also, the mass content of $\mathrm{MgO}$, $\mathrm{Fe}_{2} \mathrm{O}_{3}, \mathrm{CaO}$ and $\mathrm{Al}_{2} \mathrm{O}_{3}$, was degraded. This may be

\begin{tabular}{ccccccc}
\hline \multirow{2}{*}{ Sample } & \multicolumn{7}{c}{$\mathrm{wt} \%$} \\
\cline { 2 - 7 } & $\mathrm{SiO}_{2}$ & $\mathrm{Al}_{2} \mathrm{O}_{3}$ & $\mathrm{MgO}$ & $\mathrm{Fe}_{2} \mathrm{O}_{3}$ & $\mathrm{CaO}$ & $\mathrm{TiO}_{2}$ \\
\hline ATP & 64.5 & 13.9 & 7.54 & 8.44 & 0.19 & 1.65 \\
La-ATP & 63.3 & 13.4 & 6.16 & 8.24 & 0.06 & 1.58 \\
& $\mathrm{MnO}$ & $\mathrm{K}_{2} \mathrm{O}$ & $\mathrm{Na}_{2} \mathrm{O}$ & $\mathrm{La}_{2} \mathrm{O}_{3}$ & $\mathrm{SO}_{3}$ & $\mathrm{CO}_{2}$ \\
ATP & 0.11 & 2.39 & 0.13 & --- & 0.02 & 1.06 \\
La-ATP & 0.07 & 2.23 & 0.13 & 3.30 & 0.04 & 1.17
\end{tabular}

probably because that the attapulgite consists of a typical unit cell with $\mathrm{Mg}, \mathrm{Fe}, \mathrm{Ca}$ and $\mathrm{Al}$ cations that can be easily exchanged. Lanthanum ions may replace the cations such as $\mathrm{Mg}, \mathrm{Fe}, \mathrm{Ca}$ and $\mathrm{Al}$.

TABLE 1 THE CHEMICAL COMPOSITION OF ATP AND LA-ATP

\section{B. Adsorption isotherms}

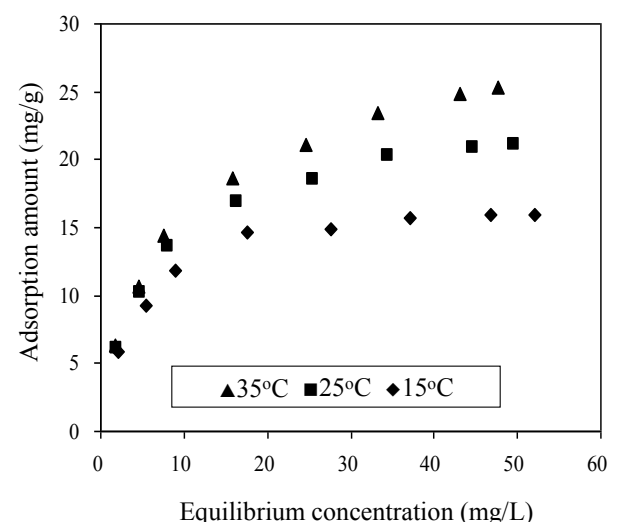

Figure 1. Adsorption isotherms of fluoride onto La-ATP at 15, 25, and
$35^{\circ} \mathrm{C}$.

TABLE 2 LANGMUIR AND FREUNDLICH ADSORPTION MODEL PARAMETERS OF FLUORIDE ADSORPTION ON La-ATP AT 15, $25 \operatorname{AND} 35^{\circ} \mathrm{C}$

\begin{tabular}{cccccccc}
\hline $\begin{array}{c}\mathrm{T} \\
\left({ }^{\circ} \mathrm{C}\right)\end{array}$ & \multicolumn{3}{c}{ Langmuir model } & & \multicolumn{3}{c}{ Freundlich model } \\
\cline { 2 - 3 } \cline { 6 - 8 } & $\mathrm{q}_{\mathrm{m}}(\mathrm{mg} / \mathrm{g})$ & $\begin{array}{c}\mathrm{b} \\
(\mathrm{L} / \mathrm{mg})\end{array}$ & $\mathrm{R}^{2}$ & & $\mathrm{n}$ & $K_{\mathrm{f}}$ & $\mathrm{R}^{2}$ \\
\hline 15 & 16.92 & 0.26 & 0.99 & & 3.38 & 5.46 & 0.92 \\
25 & 22.03 & 0.20 & 0.99 & & 2.73 & 5.53 & 0.96 \\
35 & 25.91 & 0.17 & 0.99 & & 2.43 & 5.55 & 0.97 \\
\hline
\end{tabular}

Adsorption isotherms of fluoride onto La-ATP at 15 , 25, $35{ }^{\circ} \mathrm{C}$ were illustrated in Fig .1. From the results, fluoride adsorption amount increased with the increase of equilibrium concentration of fluoride in solution. To further verify the fluoride adsorption mechanism, Langmuir model and Freundlich models were used to fit the experimental data. Langmuir model can be expressed as:

Langmuir model: 


$$
\frac{1}{q_{e}}=\frac{1}{\mathrm{q}_{\mathrm{m}}}+\frac{1}{\mathrm{q}_{\mathrm{m}} \mathrm{bC}_{\mathrm{e}}}
$$

Freundlich model:

$$
\log \mathrm{q}_{\mathrm{e}}=\log \mathrm{K}_{\mathrm{f}}+\frac{1}{\mathrm{n}} \log \mathrm{C}_{\mathrm{e}}
$$

Where $q_{e}(\mathrm{mg} / \mathrm{g})$ is the equilibrium amount adsorbed, $C_{e}(\mathrm{mg} / \mathrm{L})$ is the equilibrium concentration of fluoride, $q_{m}$ $(\mathrm{mg} / \mathrm{g})$ is the theoretical capacity adsorbed of fluoride, $b$ $(\mathrm{L} / \mathrm{mg})$ is the affinity coefficient, $K_{f}\left(\mathrm{mg}^{1-1 / \mathrm{n}} \cdot \mathrm{L}^{1 / \mathrm{n}} / \mathrm{g}\right)$ is Freundlich constant and $1 / \mathrm{n}$ is the heterogeneity factor.

Simulated parameters of adsorption isotherms by Langmuir and Freundlich model were compiled in Table 2. At 15,25 and $35^{\circ} \mathrm{C}$, the correlation factors $\left(R^{2}\right)$ based on Langmuir model $\left(R^{2}>0.99\right)$ is higher than Freundlich model $\left(R^{2}<0.97\right)$. The calculated adsorption capacity from Languir model is almost identical to the experimental data. Therefore, Languir model can fit adsorption isotherms of fluoride onto La-ATP very well, indicating of monolayer adsorption. The maximum adsorption capacity at 15, 25, and $35^{\circ} \mathrm{C}$ is $16.92,22.03$ and $25.91 \mathrm{mg} / \mathrm{g}$, respectively.

\section{Adsorption kinetics}

The adsorption kinetics of fluoride onto La-ATP at the initial fluoride concentrations of 10,30 and $50 \mathrm{mg} / \mathrm{L}$ are compiled in Fig .2. From the kinetics curves, the adsorption of fluoride was quickly in the first $10 \mathrm{~min}$ and reached the adsorption equilibrium completely within 60 min. To further describe experimental data, pseudo-firstorder and pseudo-second-order model were tested to fit the experimental kinetics data. The pseudo-first-order kinetics model is given as:

$$
\log \left(q_{e}-q_{t}\right)=\log q_{e}-\frac{k_{1}}{2.303} t
$$

The pseudo-second-order kinetics model is expressed as:

$$
\frac{t}{q_{t}}=\frac{1}{k_{2} q_{e}{ }^{2}}+\frac{1}{q_{e}} t
$$

Where $q_{e}$ is the equilibrium adsorption amount, $\mathrm{mg} / \mathrm{g}$, $q_{t}$ is the adsorption amount at time $t, \mathrm{mg} / \mathrm{g}$ and $k_{1}, k_{2}$ is pseudo-first-order and pseudo-second-order rate constant, respectively.

The simulated results are given in Table 3 . For pseudo-first-order model, the value of correlation coefficient $\left(R^{2}\right)$ is extremely low and the calculated equilibrium amount is far from the experimental values, which indicate that adsorption of fluoride onto La-ATP can not follow the pseudo-first-order kinetic model. But for pseudo-second- order kinetics, the correlation coefficient is relatively high $\left(R^{2}>0.999\right)$ and the equilibrium adsorption capacity determined by using pseudo-second order model is nearly identical with the experimental results, suggesting that fluoride adsorption onto La-ATP can be fitted by pseudo-second-order kinetics model. In addition, the rate constants of fluoride onto La-ATP decreased with increasing initial concentration, indicating of a rapid uptake rate at lower initial concentration. This may be because fluoride molecules in solution can easily find the available groups of La-ATP and attach instantly to the adsorbent surface at lower initial fluoride concentration. However, at higher initial concentration, a larger number of fluoride molecules are adsorbed on the surface of LaATP and occupy most of active adsorption sites. Fuoride molecules to be further adsorbed must overcome the electrostatic repulsion with fluoride molecules in solution and find available adsorption sites on the surface of LaATP, thus lead to a low adsorption rate.

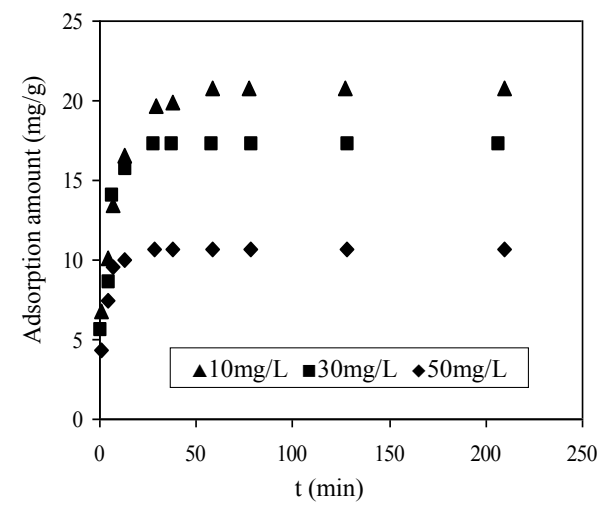

Figure 2. Adsorption kinetics of fluoride onto La-ATP at initial concentration of 10,30 , and $50 \mathrm{mg} / \mathrm{L}$.

\begin{tabular}{|c|c|c|c|c|c|c|c|}
\hline \multirow{2}{*}{$\begin{array}{c}\mathrm{C}_{0} \\
\mathrm{mg} / \\
\mathrm{L}\end{array}$} & \multirow{2}{*}{$\begin{array}{c}\mathrm{q}_{\mathrm{e}} \\
\mathrm{mg} / \mathrm{g}\end{array}$} & \multicolumn{3}{|c|}{$\begin{array}{c}\text { Pseudo-first order } \\
\text { kinetics }\end{array}$} & \multicolumn{3}{|c|}{ Pseudo-second order kinetics } \\
\hline & & $\begin{array}{c}k_{1} \\
1 / \mathrm{min}\end{array}$ & $\begin{array}{c}\mathrm{q}_{\mathrm{cal}} \\
\mathrm{mg} / \mathrm{g}\end{array}$ & $R^{2}$ & $\begin{array}{c}k_{2} \\
\mathrm{~g} /(\mathrm{mg} \cdot \min )\end{array}$ & $\begin{array}{c}\mathrm{q}_{\mathrm{cal}} \\
\mathrm{mg} / \mathrm{g}\end{array}$ & $R^{2}$ \\
\hline 10 & 10.67 & $\underset{1}{1.9 \times 10^{-}}$ & 6.61 & 0.90 & $1.0 \times 10^{-1}$ & 10.74 & 0.999 \\
\hline 30 & 17.26 & $\begin{array}{c}1.7 \times 10^{-} \\
1\end{array}$ & 14.59 & 0.92 & $3.2 \times 10^{-2}$ & 17.51 & 0.999 \\
\hline 50 & 20.81 & $\underset{2}{8.9 \times 10^{-}}$ & 14.64 & 0.98 & $1.6 \times 10^{-2}$ & 21.23 & 0.999 \\
\hline
\end{tabular}

TABLE 3. SIMULATED RESULTS OF FLUORIDE ONTO LA-ATP USING PSEUDO-FIRST ORDER AND PSEUDO-SECOND ORDER KINETICS

\section{Effect of solution $p H$}

The effect of $\mathrm{pH}$ on fluoride removal from aqueous solution by La-ATP was studied at various $\mathrm{pH}$ values (ranging from 3 to 11). As illustrated in Fig .3, it is apparent that solution $\mathrm{pH}$ has significant effect on adsorption capacity and Adsorption amount of fluoride decreased monotonously with an increase of solution $\mathrm{pH}$. Under acidic conditions, due to protonation, adsorbent surface is positively charged, which is conductive to the adsorption of fluoride. Under alkaline conditions, lower adsorption amount which may be attributed to unfavorable surface charges and competition for adsorption sites due to excess anions at alkaline conditions.

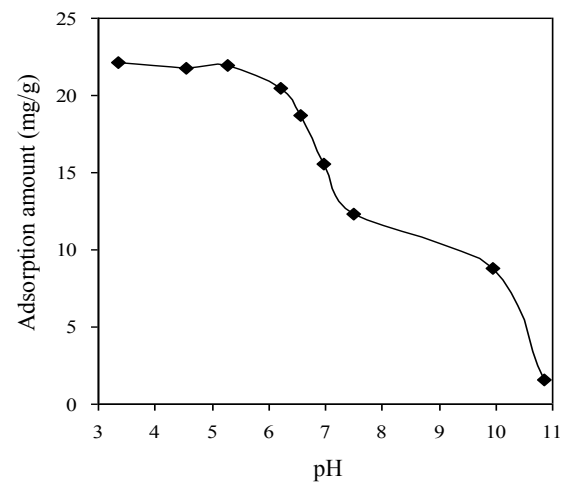

Figure 3. Effect of solution $\mathrm{pH}$ on $\mathrm{F}^{-}$adsorption on La-ATP

\section{E. Effect of competitive ions}

Drinking water and wastewater contains many competitive anions. Therefore, it was necessary to study the effect of competitive ions such as $\mathrm{Cl}^{-}, \mathrm{NO}_{3}{ }^{-}, \mathrm{SO}_{4}{ }^{2-}$, and $\mathrm{CO}_{3}{ }^{2-}$, on the adsorption of fluoride onto La-ATP [28].The 
results were given in Fig .4. It is clear that the presence of $\mathrm{Cl}^{-}, \mathrm{NO}_{3}^{-}, \mathrm{SO}_{4}{ }^{2-}$, and $\mathrm{CO}_{3}{ }^{2-}$ reduces adsorption of fluoride, and adsorption amount of fluoride decreased gradually with increasing anions concentration, which indicates that the presence of anions such as $\mathrm{Cl}^{-}, \mathrm{NO}_{3}{ }^{-}, \mathrm{SO}_{4}{ }^{2-}$, and $\mathrm{CO}_{3}{ }^{2-}$ may compete with $\mathrm{F}^{-}$in solution and decrease the adsorption of fluoride onto La-ATP. The anions reduced the fluoride adsorption in the order was $\mathrm{CO}_{3}{ }^{2-}>\mathrm{SO}_{4}{ }^{2-}>\mathrm{Cl}^{-}$ $>\mathrm{NO}_{3}{ }^{-}$. The anions $\mathrm{CO}_{3}{ }^{2-}$ showed the greatest impact for the adsorption of fluoride. This may be attributed to the change of solutioni $\mathrm{pH}$ as well as the competing effect of these co-anions after the addition of competitive ions.

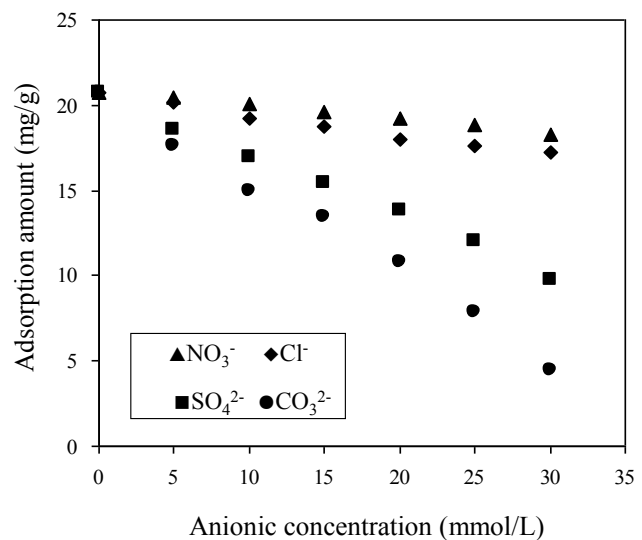

Figure 4. Effect of competitive ions on fluoride adsorption onto LaATP

\section{F. Desorption and regeneration}

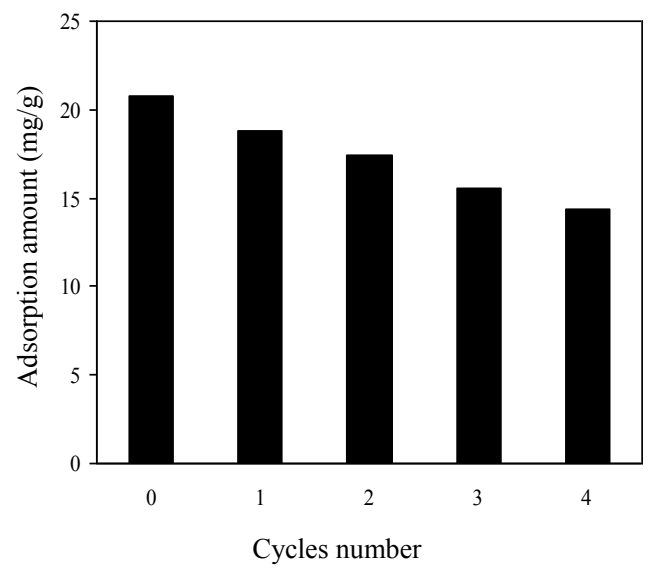

Figure 5. Desorption and regeneration histogram of fluoride onto LaATP.

From the results of Fig .3, the lower adsorption amount of fluoride on La-ATP at higher $\mathrm{pH}$ implied that fluoride loaded La-ATP can be desorbed in alkaline solution. Desorption and regeneration experiments used $0.1 \mathrm{~mol} / \mathrm{L} \mathrm{NaOH}$ solution. The results of desorption and regeneration were shown in Fig. 5. It was observed that adsorption amount of fluoride onto La-ATP decreased from $20.77 \mathrm{mg} / \mathrm{g}$ to $18.78 \mathrm{mg} / \mathrm{g}$ in the first adsorptionregeneration cycle. And adsorption amount was 14.38 $\mathrm{mg} / \mathrm{g}$ after four desorption-regeneration cycles. This result indicates that the regenerated La-ATP still possessed high adsorption capacity and had a good recycling ability.

\section{CONCLUSION}

Lanthanum modified attapulgite was prepared and used for the adsorptive removal of fluoride in aqueous solution.
Fluoride adsorption can be fitted very well by Langmuir model and the adsorption capacity increase with adsorption temperature. Adsorption kinetics follow pseudo-second kinetic model and the adsorption rates decrease with increasing initial concentration of fluoride. Adsorption amount of fluoride is highly dependent on solution $\mathrm{pH}$. The presence of competitive ions in solution decreased the fluoride adsorption amount. Fluoride adsorbed can be effectively desorbed by $\mathrm{NaOH}$ solution and regenerated adsorbents still showed high adsorption capacity for aqueous fluoride. Results imply that La-ATP is an available substitute for the adsorptive removal of aqueous fluoride in water and wastewater treatment.

\section{ACKNOWLEDGMENT}

This work was supported by National Natural Science Foundation of China (No. 21107065), Natural Science Basic Research Plan in Shaanxi Province (2012JQ2003), Innovation Program of Scientific Research Group of Shaanxi Province (2014KCT-15) and Technology Research and Development Program of Shaanxi Province (2013K13-01-07), Xi'an China.

\section{REFERENCES}

[1] X. Liao and B. Shi, "Adsorption of fluoride on zirconium (IV)impregnated collagen fiber," Environmental science \& technology, vol. 39, (2005),pp. 4628-4632.

[2] M. Sujana, R. Thakur and S. Rao, "Removal of Fluoride from Aqueous Solution by Using Alum Sludge* 1," Journal of colloid and interface science, vol. 206, (1998),pp. 94-101.

[3] X. Fan, D. Parker and M. Smith, "Adsorption kinetics of fluoride on low cost materials," Water Research, vol. 37, (2003),pp. 49294937.

[4] I. Abe, S. Iwasaki, T. Tokimoto, N. Kawasaki, T. Nakamura and S. Tanada, "Adsorption of fluoride ions onto carbonaceous materials," Journal of colloid and interface science, vol. 275, (2004),pp. 35-39.

[5] Y. Zhao, X. Li, L. Liu and F. Chen, "Fluoride removal by Fe (III)loaded ligand exchange cotton cellulose adsorbent from drinking water," Carbohydrate Polymers, vol. 72, (2008),pp. 144-150.

[6] L.M. Camacho, A. Torres, D. Saha and S. Deng, "Adsorption equilibrium and kinetics of fluoride on sol-gel-derived activated alumina adsorbents," Journal of colloid and interface science, vol. 349, (2010),pp. 307-313.

[7] Y.H. Huang, Y.J. Shih and C.C. Chang, "Adsorption of fluoride by waste iron oxide: The effects of solution $\mathrm{pH}$, major coexisting anions, and adsorbent calcination temperature," Journal of hazardous materials, vol. 186, (2010),pp. 1355-1359.

[8] M. Yang, Y. Zhang, B. Shao, R. Qi and H. Myoga, "Precipitative removal of fluoride from electronics wastewater," J. Environ. Eng., vol. 127, (2001),pp. 902-907.

[9] Y. Ku, H.M. Chiou and W. Wang, "The removal of fluoride ion from aqueous solution by a cation synthetic resin," Separation Science and Technology, vol. 37, (2002),pp. 89-103.

[10] Z. Amor, B. Bariou, N. Mameri, M. Taky, S. Nicolas and A Elmidaoui, "Fluoride removal from brackish water by electrodialysis," Desalination, vol. 133, (2001),pp. 215-223.

[11] M. Menkouchi Sahli, S. Annouar, M. Tahaikt, M. Mountadar, A. Soufiane and A. Elmidaoui, "Fluoride removal for underground brackish water by adsorption on the natural chitosan and by electrodialysis," Desalination, vol. 212, (2007),pp. 37-45.

[12] Y. Ku and H.M. Chiou, "The adsorption of fluoride ion from aqueous solution by activated alumina," Water, Air, \& Soil Pollution, vol. 133, (2002),pp. 349-361.

[13] X. Xu, Q. Li, H. Cui, J. Pang, L. Sun, H. An and J. Zhai, "Adsorption of fluoride from aqueous solution on magnesia-loaded fly ash cenospheres," Desalination, vol. 272, (2011),pp. 233-239.

[14] A.A.M. Daifullah, S.M. Yakout and S.A. Elreefy, "Adsorption of fluoride in aqueous solutions using $\mathrm{KMnO} 4$-modified activated 
carbon derived from steam pyrolysis of rice straw," Journal of hazardous materials, vol. 147, (2007),pp. 633-643.

[15] M. Karthikeyan and K.P. Elango, "Removal of fluoride from water using aluminium containing compounds," Journal of Environmental Sciences, vol. 21, (2009),pp. 1513-1518.

[16] S.S. Tripathy, J.-L. Bersillon and K. Gopal, "Removal of fluoride from drinking water by adsorption onto alum-impregnated activated alumina," Separation and Purification Technology, vol. 50, (2006),pp. 310-317.

[17] S. Samatya, ü. Yüksel, M. Yüksel and N. Kabay, "Removal of fluoride from water by metal ions $(\mathrm{Al} 3+, \mathrm{La} 3+$ and $\mathrm{ZrO} 2+$ ) loaded natural zeolite," Separation Science and Technology, vol. 42, (2007),pp. 2033-2047.

[18] [M. Srimurali, A. Pragathi and J. Karthikeyan, "A study on removal of fluorides from drinking water by adsorption onto lowcost materials," Environ. Pollut., vol. 99, (1998),pp. 285-289.

[19] S. Meenakshi, C.S. Sundaram and R. Sukumar, "Enhanced fluoride sorption by mechanochemically activated kaolinites," Journal of hazardous materials, vol. 153, (2008),pp. 164-172.

[20] N. Viswanathan and S. Meenakshi, "Selective fluoride adsorption by a hydrotalcite/chitosan composite," Applied Clay Science, vol. 48, (2010),pp. 607-611.

[21] S. Samatya, H. Mizuki, Y. Ito, H. Kawakita and K. Uezu, "The effect of polystyrene as a porogen on the fluoride ion adsorption of $\mathrm{Zr}$ (IV) surface-immobilized resin," React. Funct. Polym., vol. 70, (2010),pp. 63-68.
[22] J. Potgieter, S. Potgieter-Vermaak and P. Kalibantonga, "Heavy metals removal from solution by palygorskite clay," Minerals Engineering, vol. 19, (2006),pp. 463-470.

[23] D. Thakre, S. Jagtap, A. Bansiwal, N. Labhsetwar and S. Rayalu, "Synthesis of La-incorporated chitosan beads for fluoride removal from water," Journal of Fluorine Chemistry, vol. 131, (2010),pp. 373-377,

[24] L. Fang, K.N. Ghimire, M. Kuriyama, K. Inoue and K. Makino, "Removal of fluoride using some lanthanum(III)-loaded adsorbents with different functional groups and polymer matrices," Journal of Chemical Technology \& Biotechnology, vol. 78, (2003),pp. 10381047, 10.1002/jctb.902.

[25] S. Samatya, U. Yueksel, M. Yueksel and N. Kabay, "Removal of fluoride from water by metal ions $\left(\mathrm{Al}^{3+}, \mathrm{La}^{3+}\right.$ and $\left.\mathrm{ZrO}_{2}^{+}\right)$loaded natural zeolite," Separation Science and Technology, vol. 42, (2007),pp. 2033-2047.

[26] S.A. Wasay, M.J. Haran and S. Tokunaga, "Adsorption of fluoride, phosphate, and arsenate ions on lanthanum-impregnated silica gel," Water Environment Research, vol. 68, (1996),pp. 295-300.

[27] S.P. Kamble, G. Deshpande, P.P. Barve, S. Rayalu, N.K Labhsetwar, A. Malyshew and B.D. Kulkarni, "Adsorption of fluoride from aqueous solution by alumina of alkoxide nature: Batch and continuous operation," Desalination, vol. 264, (2010),pp. $15-23$.

[28] M. Islam and R. Patel, "Thermal activation of basic oxygen furnace slag and evaluation of its fluoride removal efficiency," Chemical Engineering Journal, vol. 169, (2011),pp. 68-77. 